\title{
Analisis Nilai Budi Pekerti Luhur Kumpulan Cerita Pendek Anak "Aku Anak Baik" Anisa Widiyarti
}

\author{
Saptono Hadi \\ Universitas Nahdlatul Ulama Blitar, Indonesia \\ Email: saptono656@gmail.com
}

\begin{tabular}{l}
\hline Tersedia Online di \\
\hline http://www.jurnal.unublitar.ac.id/ \\
index.php/briliant \\
\hline Sejarah Artikel \\
\hline Diterima pada 4 Februari 2020 \\
Disetujui pada 23 Februari 2020 \\
Dipublikasikan pada 29 Februari \\
2020 Hal. 98-112 \\
\hline Kata Kunci: \\
\hline Nilai Budi Pekerti; Cerpen Anak; \\
Anisa Widiyarti \\
\hline DOI: \\
\hline http://dx.doi.org/10.28926/briliant \\
.v3i4.435
\end{tabular}

\begin{abstract}
Abstrak: Indikasi cerita pendek anak dengan segala kisah mempesona, mengharukan, berdampak pada sikap memaksa bertindak, sehingga kekurangan perwatakan mengurangi fungsi terapan. Kesenjangan deskripsi fungsi terapan keteladanan lakuan tokoh secara jelas berimplikasi minim edukasi. Tujuan penelitian menggambarkan adanya permasalahan nilai moral dan agama sebagai bagian fungsi terapan nilai edukatif budi pekerti luhur. Pengkajian berdasar konsep pendekatan kualitatif deskripstif mengacu pada pendekatan analitik dan didaktik. Teknik observasi deskriptif sebagai upaya pemahaman dan interpretasi topik kajian. Pengumpulan data dengan menganalisis teks (kebahasaan) sebagai dokumenter yang berupa data terkait kesenjangan fungsi terapan nilai moral, dan agama. Hasil menunjukkan cerita pendek anak karya Anisa Widiyarti terdapat kesenjangan fungsi terapan nilai edukatif berbudi pekerti luhur akibat penokohan hanya menekankan adegan insiden dan kejadian.
\end{abstract}

\section{PENDAHULUAN}

Cipta sastra adalah hasil karya terindah yang mampu memberikan kenikmatan bagi pembaca yang di dalamnya termuat ide cerita yang membawa pembaca larut dan menikmati sesuai dengan karakter tokoh dalam cerita. Cerita fiksi tertulis memberikan berbagai macam model aplikasi kehidupan yang diidealkan. Karya sastra dikatakan terkandung ide-ide, yang mendeskripsikan sikap pencipta/pengarang dalam menyampaikan ekspresinya dalam kehidupan. Ide tersebut berupa gagasan-gagasan dalam memandang kehidupan dunia yang berupa sikap etika, estetika, filosofis, maupun keagamaan (religius) yang memberikan nilai lebih dan memperkaya pembaca. Sarumpaet (2010:1), penulisan memiliki kekhasan baik kata, kalimat, maupun coraknya sehingga pembacaan teruntut berperilaku khas. Membaca karya sastra dengan segala kisah mempesona, mengharukan, secara tidak langsung perilaku itu berdampak pada sikap memaksa bertindak dan berubah. Membaca cerpen mengajak pembaca kepada proses pola pikir mengenali dirinya, sesamanya, lingkungannya, dan bermacam problematik kehidupannya. Sastra merupakan deskripsi tentang duplikasi kehidupan yang mampu memanusiakan manusia (Sarumpaet, 2010:2). Maka, dikatakan sebaiknya sastra untuk anak ini merupakan bagian dari wacana sastra yang memberikan nilai lebih dengan berbagai keragaman, pertemaan, keformatan, dan karakter fungsi terapan yang anak baca. Hal yang perlu diperhatikan bahwa mengkaji sastra untuk 
anak memperhatikan sudut unsur inrinsik (poin of view, pelataran, perwatakan, plot/alur, pertemaan, gaya bahasa dan nada. Selain itu, terdapat adanya faktor kejujuran, kreatifitas tulisandengan teknik langsung yang memberikan pemahaman mengetahuan informasi secara luas mendidik. Hal ini dilakukan berdasar pada konsep bahwa pada masa kanak-kanak pemahaman terkait pemerolehan pengetahuan dasar yang mendidik akan membantu anak dalam perkembangan kejiwaan mereka. Kemampuan anak yang berupa pengetahuan dan keterampilan (ketrampilan bersosial. Ketrampilan bersekolah, ketrampilan bermain) tersebut akan membantu bersosialisasi dalam kehidupan sehari-harinya (Iskandarwassid, 2013:140). Menitikberatkan pada proses perkembangan pribadi anak baik pengetahuan kognitif, afektif, sosial, psikomotorik, serta moral dikatakan anak merupakan manusia seutuhnya memerlukan pengembangan diri. Buku cerita yang mereka baca, sesungguhnya telah menyediakan pengetahuan yang memberikan pendidikan dan dapat dikatan sebagai dasar bekal hidup ke depan. Tanuwijaya (2010: 5.5-5.6) mendeskripkan tiga karakteristik bacaan anak atau sastra anak sebagai batas beda wacana sastra dewasa, yakni (1) wacana disajikan dengan teknis langsung, (2) unsur-unsur pantangan, (3) dan terciptanya fungsi terapan wacana. Artinya, wacana anak-anak uraian penggambaran cerita disajikan dalam uraian tanpa menimbulkan makna ganda, sedangkan tema sesuai dengan dunia anak, dan funsi terapan memberikan insformasi-insformasi pola berpikir praktis bukan teoritis yang mendidik yang memberikan manfaat bagi kehidupan dunia anak dalam rangkaian keterbatasan narasi karakter tokoh melalui narasi, deskripsi, atau dialog dan mencakup rentang waktu yang pendek.

Pola berpikir praktis dimaknai bahwa budi pekerti pada sikap dan perilaku anak dalam menimbang, memilah dan menentukan kebenaran deskripsi lakuan tokoh yang dibacanya. Pada intinya konsep pola pikir praktis ini adalah melakukan tindakan yang baik dan menjauhi perilaku jelek. Alur cerita berpikir praktis dapat ditunjukkan pada deskripsi lakuan tokoh pada keteladan tokoh dalam penceritaannya. Bagi anak-anak khususnya membutuhkan wacana sesuai dunianya yang memberikan berbagai informasi mendidik, bermanfaat bagi perkembangan dirinya baik berupa pengetahuan dan keterampilan yang dapat mendidik pribadi anak melalui bacaan yang mereka baca. Melalui dunia wacana sastra pembaca anak mampu membentuk pribadinya menjadi lebih baik sehingga keseimbangan psikologisnya yang secara wajar terbentuk akan tertanamkan konsep dasar diri, mampu menentukan mana yang realistis dan berupa imajinasi. Pemahaman ini memberikan bekal anak didik dalam mencerna kelebihan atau kelemahan dirinya dalam membentuk karakter kemanusiaan. Karakter yang baik itu akan membawa anak menjadi manusia secara utuh yang memiliki pemikiran kuat dengan pribadi berkualitas budi pekerti luhur (Karma, 2014:25).

Fokus penelitian mengkaji kesenjangan fungsi terapan berbudipekerti luhur cerpen anak "Aku Anak Baik Kumpulan Cerita Menjadi Anak Baik Sesuai Tuntunan Hadits" karya Anisa Widiyarti, serta mengkaji implikasi dan tindak lanjutnya. Berdasarkan pada konteks penelitian yang ada serta teknik untuk memecahkan permasalahan tersebut, maka garis besar tujuan penelitian mendeskripsikan kesenjangan nilai budi pekerti. Selanjutnya mendeskripsikan implikasi dan tindak lanjut terhadap kesenjangan deskripsi pada nilai-nilai budi 
pekerti luhur focus nilai moral dan agama dalam cerpen. Artikel kajian sastra anak pada analisis kesenjangan deskripsi lakuan tokoh ini dapat memberikan manfaat bagi meningkatkan kualitas pengajaran berbahasa khususnya dan pelajaran lain dengan mengedepankan keterampilan berbahasa fokus sastra, meningkatkan motivasi, keaktifan, minat, bakat, dan keberanian anak didik dalam keterampilan membaca untuk meningkatkan perkembangan jiwa anak didik dalam pembelajaran sastra.

\section{METODE}

Kajian menggunakan ancangan perpustakaan, secara khusus meneliti teks, baik lama maupun baru. Pendekatan yang digunakan dalam menganalisis cerita pendek anak ini adalah pendekatan analitis dan didaktis. Sebuah ancangan kajian yang mengkaji ide, teknis pengarang menunjukkan ide serta penyikapannya melalui unsur intrinsic karya sastra yang berupa kumpulan cerpen Islami, serta keterkaitan unsur dalam ceritanya sehingga terbangun sebuah cerita. Cerpen pendek anak "Aku Anak Baik Kumpulan Cerita Menjadi Anak Baik Sesuai Tuntunan Hadits" karya Anisa Widiarti diterbitkan pada tahun 2015 sebagai acuan dalam komunikasi dengan pembacanya (anak-anak) sebagai bahan/subjek kajian. Penelitian memfokuskan masalah kesenjangan deskripsi nilai edukatif budi pekerti luhur yang ditentukan dan nilai agama lebih menekankan pada kesenjangan deskripsi fungsi terapan mengucapkan salam, shalat dan keteladanan berdoa sebagai implementasi keyakinan dan kepercayaan anak terhadap Tuhan Yang Mahaesa. Ide pemikiran tersebut sebenarnya tertuang atau dituangkan oleh pengarang melalui deskripsi baik terdata pada dialog, komentar, dan rangkaian narasi melalui alur cerita.

Sugiyono (2008:3) menjelaskan ancangan kualitatif dapat digunakan mengkaji objek yang alamiah, di mana peneliti adalah instrument kunci/inti. Pemahaman, pengidentifikasian, penganalisisan, penanfsiran terhadap fenomena kesenjangan deskripsi nilai edukatif budi pekerti luhur fokus nilai moral dan nilai agama dalam cerita pendek anak-anak hanya dapat dilakukan oleh peneliti.

Unsur-unsur pembangun sastra (cerita pendek anak), unsur instrinsik sebagai bahan pengkajian dikatakan kunci mendasar untuk menganalisis permasalahan terutama fenomena kesenjangan deskripsi nilai-nilai edukatif budi pekerti luhur. Data deskriptif kualitatif tertuang dalam kutipan teks (korpus data) berupa kutipan penggambaran perilaku tokoh sesuai sasaran yang diteliti yaitu deskripsi kesenjangan nilai edukatif (akhlak mulia dan budi pekerti) berupa ini berupa data (1) pelanggaran nilai moral (akhlak mulia/budi pekerti, (2) kesenjangan nilai agama (religi) serta (3) implikasi dan tindak lanjut terhadap kesenjangan nilai edukatif (akhlak mulia/budi pekerti) fokus nilai moral dan nilai agama. Obeservasi teks dan dokumentasi teks digunakan untuk mengumpulkan bahan data.

Prosedur pengumpulan dengan membaca cerpen anak terpilih dengan intensif dan menandai setiap bagian yang berkenaan dengan pelanggaran nilai akhlak mulia/budi pekerti luhur (edukatif) yang merupakan fokus kajian, masukkan kutipan temuan, kodefikasi, deskripsikan data temuan berdasar permasalahan, klasifikasi langkah pentabulasian, pengeditan.

Secara teoritis kajian kualitatif ini menempuh tahap: pengreduksian, sajian pendataan, penarikan simpulan (Moeloeng, 2000: 209-219). Ketiga langkah ini 
dalam prakteknya tidak dilaksanakan secara bertahap selalu diikuti dengan hasil, misalnya reduksi data sekaligus juga penarikan kesimpulan. Dapat juga terjadi pengumpulan data sekaligus sudah merupakan analisis data, misalnya dengan memasukkan ke dalam klasifikasi tertentu. Reduksi sebagai langkah penyeleksian, fokus kajian, yang dilakukan selama keberlangsungan riset. Terambil data yang dibutuhkan sesuai permasalahan kajian teranalisis yang tertuang dalam suatu rakitan informasi untuk memecahkan atau kajian. Data-data tersebut kemudian dianalisis sehingga diperoleh deskripsi tentang pelanggaran nilai akhlak mulia/budi pekerti (edukatif) fokus nilai moral dan nilai agama yang terdapat dalam cerita pendek anak tersebut. Interpretasi simpulan sebagai hasil kajian berdasarkan matrik dilakukan sejak kajian penelitian dimulai atau data didapatkan. Dalam proses ini pengkaji mengkaji makna dari berbagai hal yang ditemui di lapangan (tekstual) dengan mulai melakukan pencatatan-pencatatan, untuk mendapatkan informasi data tervalid. Kegiatan ini berkesinambungan terukur satu dengan yang lain sampai batas laporan akhir. Analisis konten terhadap konteks-konteks yang ada dalam objek penelitian digunakan untuk analisis terhadap teks data alamiah. Analisis kontens digunakan untuk memahami karya sastra dari aspek ekstrinsik. Agar diperoleh keabsahan data dan interpretasi yang tepat maka data yang diperoleh perlu diteliti kredibilitas dan interpretasinya. Pengecekan keabsahan data dilaksnakan melalui analisis wacana secara berulang terhadap teks data yang ditemukan, dilakukan komperasi melalui teknis kajian pustaka, dan trianggulasi. Membaca berulang-ulang data temuan sebagai upaya untuk memperoleh korpus data yang benar dan valid sesuai dengan kajian yang dicari. Data yang diperoleh dianalisis secara terus menerus sampai diperoleh data valid dan disimpulkan. Komperasi dengan kajian pustaka tetap dipertahankan sampai temuan terasa valid. Triangulasi (menggunakan beberapa sumber, metode, teori) dan pembahasan sejawat.

\section{HASIL}

Cerita pendek anak sebagai bagian sastra anak harus memiliki unsur imajinasi yang dominan, tidak boleh terlupakan unsur terapan. Sajian cerita yang ditampilkan harus bersifat informatif dan mengandung unsur bermanfaat dalam bentuk lakuan tindakan dalam deskripsi perwatakan tokoh-tokoh yang dijadikan teladan sikap dan perilaku langsung oleh anak. Kekurangan perwatakan dalam cerita pendek inilah menyebabkan pelanggaran terhadap nilai edukatif dalam cerita pendek anak. Nilai edukatif berbudi pekerti luhur dimaksudkan nilai yang mampu mendidik dan mengarahkan manusia menjadi manusia berbudaya, berbudi pekerti luhur, memiliki kedewasaan dalam berpikir dan bertingkah laku akhlak mulia. Hasil penelitian dinyakan bahwa ditemukan adanya keminiman edukasi karakter berbudi pekerti luhur tersebut. Tampak deskripsi etika sopan santun sebagai sikap dan perilaku terkait dengan cara bertindak dan bertutur kata tokoh sesuai dengan adat istiadat atau norma-norma yang berlaku dalam masyarakat tidak ditekankan.

Norma-norma dasar berupa etika sopan santun yang merupakan perilaku edukatif berbudi pekerti luhur akhlak mulia yang terdeskripsikan dalam lakuan tokoh, dapat dijadikan acuan membentuk kepribadian anak pada perkembangan menciptakan suasana yang kondusif dalam membudayakan budi pekerti sopan santun pergaulan di lingkungannya tidak nampak jelas. Kekurangan fungsi 
terapan adab sopan santun terjadi karena pengarang lebih fokus pada judul karangan sekaligus topik cerita. Begitu juga pada edkuasi keteladanan menjaga kesehatan bagi anak. Etika kesehatan sebagai sikap dan perilaku terkait cara bertindak menyangkut aspek psikis dan fisik, seperti mengarahkan upaya jalan berolah raga secara teratur, makan makanan yang bergizi, pola istirahat yang cukup di antaranya, serta cara membangkitkan sikap menyesuaikan disi secara konstruktif pada kenyataan, secara relative bebas dari rasa tegang dan cemas, menerima kekecewaan untuk, mengarahkan sikap perbuatan yang kreatif dan konstruktif orang yang jiwanya sehat, mempunyai rasa kasih sayang yang besar kuang ditekankan.

Pendidikan budi pekerti luhur diajarkan sebagai dasar untuk berperilaku yang berbudi pekerti luhur. Perilaku anak sebagai penikmat cerita pendek anak, perilaku yang sesungguhnya ditampilkan bukanlah hanya berada di rumah, di sekolah saja, tetapi melingkupi keseluruhan ruang lingkup di mana berada dalam masyarakat pergaulan.Kesempatan anak untuk berbuat lebih banyak, baik melakukan kegiatan bermain ataupun berbuat sesuatu lebih kompleks dengan berbagai pengaruh yang melingkupinya. Islam mengatur adab makan dan minum. Bagamana adab sebelum dan sesudah makan atau minum tertuang dalam budi pekerti akhlak mulia etika makan dan minum. Duduk dengan tertib, mencuci tangan, membaca doa, makan tidak sambil berbicara, tidak tergesa-gesa, tidak sambil berdiri, tidak boleh berceceran, meninggalkan sisa, makan secukupnya merupakan keteladan yang harus tertuang dalam lakuan tokoh dalam cerpen anak. Sehingga perilaku tersebut mampu merubah pemahaman dan pengetahuan anak yang selanjutnya berimplikasi pada perubahan perilaku mereka. Pada kajian, nalisa nilai moral keteladan adab makan dan minum ini pun kurang nampak ditekankan pengarang. Begitu juga edukasi budi pekerti dalam mengucapkan salam, yang bermakna salam berarti keselamatan, kedamaian, ketenteraman, dan keamanan. Islam dijelaskan bahwa salam merupakan sapaan resmi para malaikat, para nabi atau rasul, dan penghuni surge dan salam sebagai sarana pengikat persaudaraan. Sabda Rasulullah "Kalian tidak akan masuk surge sampai menjadi beriman. Dan tidak beriman sampai kalian saling mencintai. Maukah aku tunjukkan sesuatu yang apabila dikerjakan, kalian akan saling mencintai? Sebarkan salam di antara kalian" (HR Muslim nomor 81 dari Abu Hurairah). Selanjutnya Rasulullah saw memerintahkan agar kita senantiasa menyebarkan salam, kapan pun dan di mana pun, terutama ketika bertamu, ke rumah teman, memulai pertemuan, dan setiap kali bertemu dengan sesamanya. Jelas bahwa pembelajaran mengucapkan salam dapat memperkuat jalinan silaturahmi yang dapat menumbuhkan rasa cinta di antara umat Islam kurang penekanan karakter pada tokoh.

Jelas bahwa peranan cerita pendek memberikan peran penting bagi tumbuh berkembangnya terbentuknya watak/sifat pada anak didik usia dini. Wacana sastra anak ini sebagai bagian dari media literasi yang sangat vital unutuk diperhatikan, apalagi dalam dunia industri kreatif 4.0 seperti saat ini. Perang penting orang tua dan pencipta karya sastra terformat untuk anak harus benarbenar menjadi pertimbangan. Paling tidak pendidikan budi pekerti sebagai karakter bangsa menjadi konsep dasar yang tidak hanya dilalui melalui lakuan menghafal akan tetapi berdasarkan pada tindak tutur praktis. Pendeskripsian karakter baik melalaui narasi atau dialog dengan tepat terkait lakuan praktik akan

102 BRILIANT: Jurnal Riset dan Konseptual Volume 5 Nomor 1, Februari 2020 
berimplikasi baik pada anak sebagai pembaca dalam menanamkan nilai-nilai budi pekerti luhur tersebut.

\section{PEMBAHASAN}

Kesenyapan (tiada kegiatan: KBBI) deskripsi secara langsung dikaibatkan (1) dalam deskripsi alur/plot cerpen anak yang mengandung amanat dan pesan fungsi terapan bagian dari duplikasi kehidupan sosial hanya menampilan sekelumit kecil kejadian sehingga mengalami kemiskinan deskripsi secara total atas edukasi yang ditampilkan pada sisi deskripsi karakter tokoh dengan permasalahan yang dilakoninya. Akan memberikan dampak yang baik pada pembaca setaraf anak-anak jika lakon yang dimunculkan oleh seorang pengarang jika dibarengi dengan deskripsi yang secara langsung atas perilaku yang membawa sikap keteladanan tokoh yang bisa terbaca oleh anak. Sudah barangtentu deskripsi yang diuraikan secara langsung menjadi sarana belajar edukatif sebagai teladan anak (pembaca usia dini) (Hasanudin, 2007:598).

Pelanggaran nilai etika sopan santun ini berkaitan dengan minimnya keteladanan dalam cerita pendek anak akan penggambaran watak-watak tokoh yang jelas atas nilai etika sopan santu tokoh, yang tergambarkan melalui lakuan alur tokoh, yang seharusnya dapat dijadikan keteladan bagi anak sebagai pembaca. Pengarang lebih menekankan pada aspek penyajian cerita yang mengungkapkan kejadian-kejadian saja tanpa memperbanyak deskripsi lakuan perwatakan tokoh dalam kehidupan keseharian.

Karya Anisa Widiyarti ini sudah dapat dikatakan memiliki prasyarat cerita pendek anak yang memiliki kesederhanaan, komunikatif, dan sudah memberikan alur cerita. Pada dasarnya karya ini sudah cukup menguraikan beberapa topik dengan tokoh anak dengan berbagai ide kejadian tentang dunia anak. Rancang bangun isi wacana yang berupa pesan moral melalui amanat tertuang dalam judul cerita, artinya kesederhaan judul telah memberikan penjelasan ke arah mana amanat akan diberikan kepada pembaca. Dapat dikatakan topik yang teruraikan dinyatakan terbuka dan gamblang. Pada alur yang terbentuk sudah memunculkan konflik-konflik tertentu, misal denagn dirinya sendiri, dengan orang lain, baik dalam lingkup kecil dan kehidupan bermasyarakat. Namun, karena kurangnya ketajaman Anisa dalam mendeskripsikan secara langsung baik melalaui dialog atau narasi pada keteladanan sang tokoh, maka karya Anisa ini menyebabkan terjadi kesenyapan ketajaman karakter. Selayaknya cerita pendek anak ini memberikan unsur imajinasi yang jelas secara langsung menunjukkan antara baik dan buruk sebagai unsur perilaku praktis yang informatif-edukatif dan tidak terkesan dominan pada lakuan teoritis sebagai bagian dari fungsi terapan sebuah karya sastra anak. Bentuk lakuan tindakan ini sebagai keteladanan perilaku anak sebagai pembaca dalam setiap deskripsi perwatakan tokoh-tokoh sehingga mampu memberikan wawasan atau pandangan sikap dan perilaku langsung bagi anak. Kekurangan dan minimnya deskripsi lakuan perwatakan etika sopan santun pada tokoh anak dalam cerpen anak "Aku Anak Baik Kumpulan Cerita Menjadi Anak Baik Sesuai Tuntunan Hadits" karya Anisa Widiyarti menyebabkan pelanggaran terhadap nilai edukatif etika keteladanan sopan santun sebagai salah satu nilai budi pekerti luhur edukatif sastra anak terjadi.

Hal itu terlihat pada ku Kutipan 2, MO-c1/7 sebagai berikut. 
Ketika melihat kami, anak perempuan itu tersenyum. Sepertinya, ia merasa senang karena melihat ada anak lain yang seuasia dengannya. Saat kami sudah dekat dengannya, tiba-tiba ia menyapa kami. "Hai, boleh kenalan, enggak?" sapanya. "Boleh, dong," jawab Caca yang langsung turun dari sepeda. Sementaraa aku, Danu, dan Pandu diam saja. Aku mengamati anak itu sambil menahan tawa. Bagaimana tidak? Anak perempuan itu rambutnya kribo, kulitnya juga hitam (M-MO-c1/PSs/7).

Kutipan 3, MO-c1/8

"Hei, kalian kenalan juga, dong," ucap Caca. Aku, Danu, dan Pandu hanya berpandangan, kami tak bisa lagi menahannya. Kami pun tertawa terbahakbahak. "Hlo, kenapa kalian malah tertawa?" Tanya Caca bingung. "Desi, kamu, kok, hitam banget, sih?" Tanya Danu di sela tawanya. "Iya, sudah hitam, kribo lagi," tambahku. Desi terlihat sedih mendengar ucapanku dan Danu, namun, kami masih terus tertawa (M-MO-c1/PSs/8)

Dalam kutipan cerpen "Mengatai Orang" di atas terlihat gambaran yang kurang tepat diberikan kepada anak sebagai pembaca. Terlihat contoh sikap dan perilaku pergaulan yang kurang terpuji bagi anak yang ditunjukkan tokoh Aku (Arkaan), Danu dan Pandu yang tidak mau turun dari sepeda ketika ada anak yang mengajaknya berkenalan, berbincang-bincang. Kemudian mentertawakan sebagai sikap menghina akan keberadaan seseorang yang berbeda dan unik. Sikap dan perilaku yang kurang terpuji ini akan membawa dapak yang kurang baik bagi mental diri anak. Dapat memberikan keteladanan yang baik jika pendeskripsian lakuan tokoh tersebut memberikan gambaran keteladanan sopan santun pergaulan yang berbudi pekerti luhur. Seperti anak diarahkan pada keteladanan turun dari sepeda, berjabat tangan bertemu dengan teman dan sebelum melakukan perbincangan atau membicarakan masalah tertentu. Bukan perilaku dan sikap tidak hanya dengan posisi di atas sepeda sebagai penanda ajaran sikap tidak terciptanya pola sopan santun dalam pergaulan dengan teman.

Pada kutipan Kutipan 3, MO-c1/8 akan membentuk jiwa anak pada perilaku dan sikap sombong atau tinggi hati, melupakan dan tidak menyadari nikmat Yang Maha Kuasa dan tidak ada yang kekal, selayaknya tidak terdeskripsikan perilaku menghina. Kurangnya tata nilai etika keteladanan sopan santun pembiasaan berbicara yang baik pada orang tua atau yang lebih tua ini juga terlihat pada Kutipan 15, IKM-c5/29-30 sebagai berikut.

Lho, sepatu dan kaus kakinya, kok, berceceran seperti ini?" Tanya Mama. "Rapikan dulu dong! "Nanti saja, ya, Ma," jawabku cepat. "Bik Nah, tolong ambilkan bajuku, dong!" seruku lagi sambil berlari mengambil robot tempurku di kotak mainan. Tergopoh-gopoh Bik Nah datang. "Ini bajunya". Aku segera membuka baju seragamku. (M-IKM-c5/PSs/:30).

Etika sopan santun ini dikatakan mengkaji pada unsur deskripsi seseorang pada sudut pandang cara melakukan sesuatu melalui tindak tutur yang mengacu pada hukum etika bermasyarakat dan terwujud melalui hubungan yang harmonis baik dalam keluarga anak, dengan diri anak, maupun ketika anak berada di lingkungan sekolah dan kehiudpan bermasyarakat. Deskripsi yang tertuang pada narasi cerita dan dialog lakuan kehidupan serta pergaulan tokoh yang dibentuk pengarang melalui karyanya berupa cerita pendek anak.

Norma-norma dasar yang berupa etika sopan santun yang merupakan perilaku edukatif berbudi pekerti luhur akhlak mulia yang terdeskripsikan dalam 
lakuan tokoh tersebut hendaknya dapat dijadikan acuan untuk membentuk kepribadian anak pada perkembangan etika sopan santun pergaulan di lingkungannya. Terlihat deskripsi tokoh Arkaan dalam kalimat kutipan tersebut tidak tergambarkan.

Kurangnya edukasi keteladanan etika sopan santun berpakaian terlihat pada Kutipan 16, IKM-c5/29-30 berikut.

Iya, tapi jangan di sini, dong," kata Pandu. "Memang kenapa, sih?" protesku sudah tak sabar. "Malu, dong," jawab Danu. "Ah, kita kan sama-sama cowok," aku membantah. "Tapi auratnya nanti terlihat," kata Mama sambil tersenyum. "Aurat laki-laki, kan, dari pusar hingga lutut". Aku cemberut. "Iya, deh," jawabku kesal sambil berjalan menuju kamar.

"Huh, maksudku biar lebih cepat, malah jadi lama," gerutuku sambil menutup pintu kamar. Memang apa salahnya ganti nbaju di depan teman? (M-IKM-c5/PSs/30).

Teladan bagian dari konsep dasar bagi pembelajaran untuk anak didik pada laku luhur dan akhlak mulia (Basuki, 2013: 8-9). Pembelajaran etika ini secara kontinyu memberikan pengetahuan anak yang berimplikasi pada keterampilan bertindak tutur. Nilai edukatif budi pekerti luhur merupakan amanat moral/edukatif yang mampu memberikan titik arahan anak kepada diri yang berintelek-budaya berbudi pekerti luhur, sehingga kemampuan bertindak ini mendewasakan anak untuk berakhlak mulia. Pelanggaran terhadap nilai edukatif pembiasaan adab bertemu atau bertatap muka tampak seperti tidak mengucapkan salam, menyapa, dan berjabat tangan. Tingkah laku orang Islam khususnya hal semacam ini mencerminkan akhlak terpuji. Mengucapkan salam, menyapa, dan berjabat tanngan dalam setiap pertemuan atau bertemu merupakan teladan yang baik bagi anak. Bagi umat Islam, salam merupakan budaya, etika atau adab dalam menyapa baik kepada sesama, kepada nabi/rasul, dan penikmat firdaus (Q.S. azZariyat/51). Bentuk lain salam sebagai sarana pengingkat persaudaraan. Jelas bahwa salam dapat memperkuat jalinan silaturahmi yang menumbuhkan rasa cinta antarumat. Kondisi bangsa Indonesia yang majemuk dan perbedaan suku yang menonjol merupakan kondisi yang tepat untuk menyebarkannya. Keteladanan salam dalam etika nilai edukatif dalam cerpen anak sebagai keteladanan sangatlah memegang peranan penting bagi diri anak.

Pelanggaran nilai moral keteladanan etika menjaga kesehatan yang ditemukan peneliti setelah menganalisis data temuan adalah pelanggaran yang berkaitan dengan tidak atau kurang terdeskripsikannya sikap dan perilaku seperti tidak menjaga kebersihan tangan setelah bermain dengan hewan (dalam cerpen tersebut di tokohkan kucing), pola makan atau tidak makan sepulang sekolah, istirahat tidur siang, pada tokoh Arkaan, Danu, dan Pandu yang merupakan tokoh dari dua belas judul karya Anisa Widiyarti. Basuki (2013: 2-3) menjelaskan bahwa etika kesehatan merupakan hal yang menyangkut aspek psikis dan fisik. Kesehatan fisik dalam deskripsi tokoh dalam cerita pendek anak terdeskripsikan pada keteladanan lakuan tokoh yang mengarahkan upaya pola makan dan pola istirahat yang cukup. Sedangkan kesehatan psikis dalam deskripsi lakuan keteladanan tokoh pada cerpen anak hendaklah terdeskripsikan dengan cara membangkitkan sikap seperti menyesuaikan diri walau memberikan tantangan, secara relative bebas akan rasa tegang dan cemas, serta menjunjung perasaan saling menghormati lebih tinggi. 
Pelanggaran dapat dikatakan pada cerita pendek anak tidak terdeskripsikan lakuan tokoh pada contoh atas keteladanan uraian tentang nilai moral etika kesehatan. Pelanggaran nilai moral etika keteladanan kesehatan itu terpaparkan pada kutipan sebagai berikut.

Kutipan 1, MO-c1/6

Sore itu, aku, Danu, Pandu, dan Caca sedang bersepeda. Kami memang sering bersepeda bersama jika tugas sekolah kami sedang tidak banyak. Soalnya, bersepeda bersama itu asyik. Kami bisa melihat pemandangan di sekitar dan kaki kami tidak pegal karena berjalan kaki (M-MO-c1/PMk/7)

Kutipan 11, SY-c4/26

"Masih mau lanjut?" jawabku. "Tapi, sepertinya sudah siang, nih. Sudah panas begini," kata Danu. Aku mengangguk. Benar juga, sih. Sebenarnya, sejak tadi aku juga sudah merasa kepanasan. Namun, karena permainan sedang seru, aku tak menghiraukannya. "Lanjut saja, deh!” seru Rangga. "Timku masih ketinggalan, nih." Akhirnya, kami menyetujui usul Rangga. Kami pun kembali bermai (M-SY-c4/PMk/26).

Pada kutipan 1, MO-c1/6 dan 11, SY-c4/26 di atas pola pembelajaran pada anak pada etika pemahaman wawasan penanaman untuk menjaga kesehatan badan tidak terdeskripsikan. Anisa Widiyarti pada kenyataannya lebih terfokuskan pada topik dan lakuan tokoh anak yang hanya senang bermain saja. Keteladanan budi pekerti luhur berkaitan dengan menjaga kesehatan itu penting bagi anak tidak terdeskripsikan. Uraian bahwa tidur siang sebagai istirahat yang baik, makan yang terartur dengan makanan bergizi tidak terdeskripsikan sedikit pun. Hal semacam ini jelas menunjukkan kurang terdeskripsikan nilai edukatif bagi anak. Nilai terapan yang seharusnya menjadi teladan tidak terdeskripsikan.

Selayaknya Anisa Widiyarti berani mendeskripsikan lakuan tokoh dengan menguraikan beberapa kegiatan tokoh Danu, Pandu, Caca, dan Arkan sebelum bersepeda di sore hari dengan uraian bahwa apa yang mereka lakukan itu setelah mereka selesai menyelesaikan tugas, shalat Ashar, dan berpamitan atau ijin kepada orang tua dengan kegiatan yang akan dilakukan. Dan pada kutipan 11, SYc4/26 tersebut selayaknya diberikan gambaran perlunya beristirahat yang cukup untuk kesehatan fisiknya. Sehingga ketika anak membaca ilustrasi tersebut, mereka mempunyai bayangan yang baik bahwa segala sesuatu di aman dan kapan saja akan dilakukan akan lebih baik jika dikerjakan setelah tugas belajar selesai, beristirahat yang cukup, makan makanan bergizi, dan dengan ijin kepada orang tua.

Paling tidak dalam deskripsi lakuan karakter tokoh, dalam keteladanan bersih itu sehat, bagian dari iman itu perlu dipertajam. Makna bersih selayaknya dapat ditekankan pada pemahaman lakuan diterapkan pada kehidupan sehari-hari kapan dan di mana pun anak berada. Terdapatnya penjelasan etika mencuci tangan, makan makanan yang sehat, berpikir yang jernih, membuang sampah pada tempatnya, dan sebagainya baik secara fisik dan batin sesuai norma budi pekerti luhur akhlak mulia sehingga terbentuk kebudayaan pada pribadi anak yang baik dan terarah. Pembentukan suasana watak budi pekerti luhur yang konsisten pada lakuan karakter tokoh dalam cerpen merupakan salah satu modal utama dalam pembentukan watak bagi diri anak.

Peranan cerita pendek memberikan peran penting bagi tumbuh berkembangnya terbentuknya watak/sifat pada anak didik usia dini. Wacana sastra

106 BRILIANT: Jurnal Riset dan Konseptual

Volume 5 Nomor 1, Februari 2020 
anak ini sebagai bagian dari media literasi yang sangat vital unutuk diperhatikan, apalagi dalam dunia industri kreatif 4.0 seperti saat ini. Perang penting orang tua dan pencipta karya sastra terformat untuk anak harus benar-benar menjadi pertimbangan. Paling tidak pendidikan budi pekerti sebagai karakter bangsa menjadi konsep dasar yang tidak hanya dilalui melalui lakuan menghafal akan tetapi berdasarkan pada tindak tutur praktis. Pendeskripsian karakter baik melalaui narasi atau dialog dengan tepat terkait lakuan praktik akan berimplikasi baik pada anak sebagai pembaca dalam menanamkan nilai-nilai budi pekerti luhur tersebut.

Islam mengatur adab makan dan minum. Bagamana adab sebelum dan sesudah makan atau minum tertuang dalam budi pekerti akhlak mulia etika makan dan minum. Duduk dengan tertib, mencuci tangan, membaca doa, makan tidak sambil berbicara, tidak tergesa-gesa, tidak sambil berdiri, tidak boleh berceceran, meninggalkan sisa, makan secukupnya merupakan keteladan yang harus tertuang dalam lakuan tokoh dalam cerpen anak. Secara garis besar nilai ini terkait benarsalah sama dengan logika, terkait dengan baik-buruk dengan etika, dan berhubungan dengan indah-tidak indah dengan estetika. Sehingga pembelajaran ditujukan pada anak dalam tindak laku dan tindak tuturnya tetap berdasarkan pada etika beradab (Basuki, 2013:1). Nilai budi pekerti luhur aklahk mulia etika atau adab dalam hal makan dan minum ini sebagai etika yang menjadi contoh anak berbudi pekerti luhur, dewasa berpikir akhlak mulia dalam berperilaku dalam makan dan minum (Kosasih, 2012:46).

Pelanggaran terhadap nilai moral keteladan adab makan dan minum dalam kumpulan cerita pendek karya Anisa Widiyarti ini terjadi karena deskripsi pada sikap dan perilaku yang bertentangan dengan ajaran di atas. Atau dapat dikatakan pada cerita pendek karya Anisa Widiyarti ini kurang atau tidak mendeskripsikan sikap perilaku lakuan tokoh pada contoh atas nilai moral etika adab makan dan minum. Pelanggaran nilai moral etika keteladanan adab makan dan minum terpaparkan pada kutipan sebagai berikut.

Kutipan 6, MM-c2/15

Mama terlihat senang sekali. Aku jadi ikut senang. Aku, Danu, dan Pandu langsung tersenyum. Ternyata Mama memberi kami hadiah. Tiga gelas es sirop yang menyegarkan! "Hmmm, segar....," kata Danu dan Pandu. "Rasa hausku langsung hilang," kataku (M-MM-c2/PMM/15).

Keteladanan merupakan salah satu inti keluhuran dan akhlak mulia (Basuki, 2013: 8-9). Belajar teladan secara aktif-inovatif akan membentuk anak lebih tangguh. Nilai edukatif berbudi pekerti luhur akhlak mulia akan terbentuk dengan sendirinya bersama perkembangan tindak tutur sehari-hari.

Dalam Islam dijelaskan bahwa sabda Nabi Muhammad saw, "Kalian tidak akan masuk surge sampai menjadi beriman. Dan tidak beriman sampai kalian saling mencintai. Maukah aku tunjukkan sesuatu yang apabila dikerjakan, kalian akan saling mencintai? Sebarkan salam di antara kalian” (HR Muslim nomor 81 dari Abu Hurairah). Selanjutnya Rasulullah saw memerintahkan agar kita senantiasa menyebarkan salam, kapan pun dan di mana pun, terutama ketika bertamu, ke rumah teman, memulai pertemuan, dan setiap kali bertemu dengan sesamanya. Jelas bahwa pembelajaran mengucapkan salam dapat memperkuat jalinan silaturahmi yang dapat menumbuhkan rasa cinta di antara umat Islam.

Pelanggaran terhadap nilai agama etika mengucapkan salam ini terjadi pada suasana sikap dan perilaku tokoh, terutama tidak terdapatnya keteladan 
mengucapkan salam itu dalam rangkaian alur karakter tokoh yang diperankan dalam cerpen. Atau dapat dikatakan pada cerita pendek anak itu tidak atau kurang jelas menekankan deskripsi sikap perilaku lakuan tokoh atas nilai keagamaan etika pembelajaran melaksanakan/mengucapkan salam dalam diri anak melalui deskripsi lakuan tokoh dalam cerita. Pelanggaran nilai agama etika mengucapkan salam terpaparkan pada kutipan sebagai berikut.

Pada kutipan 2, MO-c1/7 ini tidak terdapat deskripsi anak Islami jika bertemu atau bertatap muka dengan teman mengucapkan salam atau pun berjabat tangan. Terdeskripsikan tokoh Arkan dkk yang masih tetap dengan sepedanya. Gambaran tentang pelanggaran keteladanan terhadap nilai agama (ketakwaan) pada anak fokus pelanggaran pembiasaan adab mengucapkan salam secara Islami (norma agama). Kutipan 3, MM-c2/11pelanggaran terjadi pada deskripsi antara tokoh Mama dan arkan. Keteladanan mengucapkan salam dari orang tua terhadap anaknya atau sebaliknya tidak tergambarkan. Apalagi karakter Islami seperti mencium tangan orang tua pun tidak terdeskrisikan. Seandainya Anisa Widiyarti memahami dan jeli, sudah barang tentu, penambahan deskripsi karakter nilai Islami terhadap siakp dan perilaku tokoh akan menjadi teladan yang baik bagi anak sebagai pembaca. Gambaran tentang pelanggaran keteladanan terhadap nilai agama (ketakwaan) pada anak fokus pelanggaran pembiasaan adab mengucapkan salam secara Islami dan adab taat kepada orang tua.

Kutipan 4, MM-c2/12

Aku kan sedang asyik bermain. Lagi pula, kenapa bukan Mama yang membeli sendiri, sih? "Mama minta tolong, ya. Sekarang, Mama mau membantu Bik Nah merapikan rumah dulu. Malu kalau ada tamu, rumahnya masih berantakan," ucap Mama lagi sambil tersenyum. Lalu, kembali ke rumah. (A-MM-c2/PKus/12)

Pelanggaran terhadap nilai agamis budi pekerti luhur pembiasaan adab mengucapkan salam tampak seperti bertemu atau bertatap muka, tidak menyapa, dan berjabat tangan. Tingkah laku orang Islam khususnya hal semacam ini mencerminkan akhlak tidak terpuji. Mengucapkan salam, menyapa, dan berjabat tangan dalam setiap pertemuan atau bertemu merupakan teladan yang baik bagi anak. "Apabila salah seorang di antara kalian bertemu dengan saudaranya, hendaklah ia mengucapkan salam kepadanya. Seandainya di antara keduanya terpisah oleh pohon, dinding, atau batu, kemudian bertemu kembali, hendaklah ia mengucapkan salam lagi" (HR Abu Dawud dari Abu Hurairoh).

Bagi umat Islam, salam merupakan budaya dan etika bersosialisasi. Bentuk lain salam sebagai sarana pengingkat persaudaraan. Jelas bahwa salam dapat memperkuat jalinan silaturahmi yang menumbuhkan rasa cinta antarumat. Kondisi bangsa Indonesia yang majemuk dan perbedaan suku yang menonjol merupakan kondisi yang tepat untuk menyebarkannya. Keteladanan salam dalam etika nilai edukatif dalam cerpen anak sebagai keteladanan sangatlah memegang peranan penting bagi diri anak.

\section{Implikasi dan Solusi}

Berdasarkan data terkaji, terambil sebuah hasil penelitian yang bersifat kualitatif. Hasil penelitian pada kumpulan cerita Islami karya Anisa Widiyarti ini terdeteksi adanya kesenjangan edukasi nilai edukatif berbudi pekerti luhur pada 
titik fokus nilai moral dan nilai agama yang dapat memberikan dampak pada diri anak sebagaipembaca.

Lebih lanjut dampak yang mungkin terjadi pada anak tersebut timbulnya bermacam-macam masalah-masalah moral dalam berkehidupan misalanya dekadensi etika, anjlognya perilaku adab yang baik, tidak jujur meningkat, menurunnya rasa hormat kepada guru/orang tua, meningkatnya kelompokkelompok fanatik, bertindak tutur kotor, sikap pada anak buruk, berbahasa tidak jelas arah tujuan, menurunya semangat belajar, egoisitas tinggi dan tidak jujur, tidak ada kepedulian yang iklas dan disiplin, timbulnnya gelombang perilaku yang merusak diri sendiri, menipisnya kesopanan pada diri anak, mengabaikan pengetahuan nilai moralitas dan nilai agama.

Berdasar pada situasi tersebut solusi yang dapat disarankan penulis sebagai berikut (1) terhadap pengarang, selayaknya pengarang memperhatikan penyajian perwatakan tokoh yang dapat menujukkan nilai moral dan nilai agama yang jelas sebagai keteladanan anak sebagai pemabaca. Pendeskripsian setiap tokoh baik protagonis, antagonis maupun tritagonis paling tidak diberikan deskripsi ke arah lakuan berbudi pekerti luhur tersebut. Pengarang harus tetap berpijak pada fungsi terapan cerita pendek anak yang diperuntukkan untuk anak dengan gaya bahasa anak. Pengarang tetap memberikan deskripsi yang membiasakan akhlak berbudi pekerti luhur terpuji dan menghindari akhlak tercela; memberikan perwatakan sikap dan perilaku berpikir praktis anak dalam hidupnya; memberikan keteladanan sikap dan perilaku anak pada berpikir produktif yakni berhubungan pada keteladanan sikap dan perilaku untuk menemukan atau mendapatkan cara yang terbaik untuk mencapai tujuan hidup anak selanjutnya ke arah tujuan yang berbudi luhur. (2) Terhadap orang tua, sebaiknya orang tua harus lebih selektif terhadap bacaan cerita pendek anak yang diberikan kepada anak. Pembimbingan dalam memaknai terhadap lakuan penokohan tetap menjadi tinjauan yang harus dilakukan untuk anak sehingga anak benar-benar mendapatkan tuntunan dan arahan. Perkembangan mental anak yang terarah dan terbimbing dengan tepat akan tercipta karakter yang baik berbudi pekerti luhur sehingga muncul rasa cinta, hormat kepada orang tua akan tercerminpada sikap dan perilakunya; (3) Terhadap pendidik, lebih proaktif merespon gejala kemerosotan moral anak didik, pendidik sebaiknya secara umum peningkatan dan intensitas pelaksanaan pendidikan moral yang dilaksanakan secara komprehensif terutama dalam analisis cerita pendek anak. Pendidik lebih jeli pada PBM sastra atau bahasa Indonesia dalam kajian cerita dan bercerita sebagai keterampilan berbahasa. Selanjutnya pendidik selayaknya dapat melakukan identifikasi dana analisis keperluan anak sebagai peserta didik dalam kajian edukasi cerita pendek sebagai bahan kajian dalam proses pendidikan anak. Pendidik dapat memberikan bantuan peserta didik dalam pengembangan pola berpikir praktis sehingga penalaran anak berpikir kreatifinovatif sesuai perkembangan intelektual dan psikologis anak ke arah perbaikan kehidupan dan perkembangan dirinya.

Solusi secara umum kajian edukatif nilai religius cerita pendek anak, sebaiknya perlu memperhatikan dan memahami bahwa kekuatan iman dan taqwa berpengaruh pada sikap sehari-hari anak. Maka kontekks imam ini perlu mendapat perhatian pembinaan untuk dikembangkan pada diri anak. Keimanan yang tangguh dan kuat pada diri anak akan menuntun pada diri berbudi luhur. Sastra, dalam hal ini, bacaan cerita pendek anak yang menjadi konsumsi menarik bagi 
anak merupakan media yang tepat untuk meningkatkan keimanan dan ketaqwaan pembaca melalui alur cerita yang lugas, jujur, dan berkonsep dasar lakuan praktis yang terwujud pada karakter tokoh dalam melaksanakan perilaku beragama sebagai cerminan pesan dan amanat nilai religius. Sudah selayaknya pengarang dengan melihat asumsi tersebut, maka disetiap deskripsi penokohan alangkah indahnya jika diberikan deskripsi akan keimanan, ketaqwaan, ketauhidan sehingga menggambarkan sikap dan perilaku nilai moral dan beragama yang berbudi pekerti luhur akhlakul karimah pada tokoh-tokohnya sebagai bentuk kepatuhan kepada Tuhan.

\section{KESIMPULAN}

Cerita pendek anak yang baik mengandung nilai-nilai edukatif yang berfungsi terapan sebagai tuntunan perkembangan jiwa dan pola pikir anak. Fungsi terapan ini memberikan kemanfaatan estetis yang mendidik anak pada kepekaan berpikir (kognitif, psikomotorik, psikologis) dan bersosial sehingga anak terbawa pada perkembangan jiwa/kepribadian sesuai etika yang baik. Manfaat estetis pada anak, berarti anak akan mendapatkan pengalaman keteladan tentang hiburan membaca cerita pendek, mendapatkan kepuasan yang sesuai dengan karakter dan perkembangan jiwa anak, dan kebahagiaan batin atas cerita yang terbacanya. Manfaat wawasan itu sendiri bagi anak akan memberikan tambahan informasi, pengetahuan, keteladanan pengalamanhidup, dan pandangan tentang kehidupan yang baik bagi dirinya.

Sedang pada manfaat edukatif, anak akan mendapatkan keteladanan karakter berbudi pekerti luhur akhlak mulia terhadap kajian perubahan perilaku atau kelompok yang dipetik dari sikap dan perilaku tokoh. Selanjutnya anak akan terasah batin dan pola pikirnya kearah karakter berbudi pekerti luhur akhlak mulia, anak akan dapat menjalani kehidupan sehari-hari menjadi teladan. Selanjutnya anak akan memiliki kemampuan menghubungkan pengalaman dari yang dibacanya dengan keberadaan pengalaman di luar cerita. Jika cerita pendek anak tersebut tidak mengarahkan kepada perilaku karakter berbudi luhur akhlak mulia, berimplikasi negatif bagi diri dan pola pikir anak dalam kesehariannya. Sebuah cerita pendek yang tidak memberikan nilai edukatif dan religius yang baik akan memberi dampak yang tidak bermanfaat, yang mempengaruhi kejiwaan anak, memberikan ambiguitas diri anak yang menyebabkan kebimbangan dan kebingungan terhadap sebuah konsep tertentu, yang selanjutnya berimplikasi pada pola pikir dan perilaku ke arah perilaku negatif tidak terpuji. Muncul suatu sikap tidak mengenal sopan santun, tidak menghormati orang tua atau guru, corat coret tembok semaunya, atau sikap-sikap negatif lainnya. Selanjutnya sudah dapat dipastikan angka kriminalitas dan kenakalan remaja yang meningkat.

Pengarang seharusnya tetap menyadari dan memahami bahwa cerita pendek anak itu merupakan cerita untuk anak yang nilai estetis lebih mendasar bermedium bahasa lugas baik lisan/tulis yang dikerjakan khusus untuk anak sesuai tingkatan usia, bersifat imajinatif praktis bukan teori sehingga mampu dimengerti pembaca anak sesuai dunia anak dalam masa perkembangan pola pikir yang memerlukan tuntunan dengan tepat. Dari pemahaman seperti ini selayaknya pengarang memahami betul bahwa sasaran dari cerita yang diciptakannya adalah diri pembaca anak. Jadi ciri dan hakikat cerpen anak sebaiknya disesuaikan 
dengan kehidupan alam anak yang membedakan dengan serita pendek untuk orang dewasa.

Baginya, menurut anggapan anak, segala sesuatu baik benda mati ataukah hidup, berjiwa ataukah tidak, setiap benda itu dianggapnya memiliki imbauan dan nilai tertentu yang pada dasarnya bagi mereka bisa dianggap sebagai pedoman perilaku dalam alam kehidupannya sehari-hari. Maka sudah selayaknya pengarang dengan berpedoman pada sikap ini dalam penciptaan cerita pendek harus memperhatikan nilai-nilai tersebut terutama berkaitan dengan nilai-nilai edukatif, tidak hanya sekedar berfokus pada tujuan dari pesan moral nilai baik dan buruk yang berfokus pada judul saja. Dalam arti pengarang dalam penyajian penokohannya melupakan penggambaran pada titik deskripsi perilaku tindak tanduk tokoh dalam karakter hubungan dengan tokoh yang lain dengan lakuan keteladan sikap dan perilaku nilai edukatif dan religius baik dalam deskripsi lakuan maupun dalam dialognya.

\section{SARAN}

Penelitian ini diharapkan dapat dijadikan tolok ukur dalam pembelajaran kajian apresiasi cerita pendek anak analisis pelanggaran nilai-nilai budi pekerti luhur yang menarik, kreatif, dan inovatif. Pembelajaran keterampilan membaca haruslah merupakan tindakan yang pertama dilakukan, sehingga dengan kemampuan membaca yang baik, terjadi kemudahan anak menikmati cerita pendek yang dibacanya. Selanjutnya terdapat gairah untuk membaca wacana lain yang menarik bagi anak. Pendidik lebih berhati-hati dan selektif dalam pemilihan bahan ajar cerita pendek anak dalam pembelajaran apresiasi sastra khususnya analisis edukatif dan relligius serta problematik keduanya. Hasil penelitian ini dapat memberikan tolok ukur atas jawaban dari masalah yang sesuai dengan perumusan masalah. Hasil penelitian ini mampu menjadi pendorong pembaca dalam memberikan pembelajaran keteladan pembinaan anak sebagai sumber daya manusia yang berkarakter bangsa

\section{DAFTAR RUJUKAN}

Aminuddin. 2013. Pengantar Apresiasi Karya Sastra. Bandung: Sinar Baru Algesindo.

Basuki, dkk.. 2013. Pedoman Penciptaan Susana Sekolah Yang Kondusif Dalam Rangka Pembudayaan Budi Pekerti Luhur Bagi Warga Sekolah. Jakarta: Ditjen Dikdasmen Depdiknas.

Endraswara,S. 2008. Metodologi Penelitian Sastra. Epistemologi, Model, Teori, dan Aplikasi (Edisi Revisi). Yogyakarta: Medpres.

Gani, R. 2007. Pengajaran Sastra Indonesia. Respon dan Analisis. Jakarta: P2LPTK.

Hasanuddin, T., dkk. 2009. Kesastraan. Departemen Pendidikan Nasional. Direktorat Jenderal Peningkatan Mutudan Tenaga Kependidikan. Pusat Pengembangan dan Pemberdayaan Pendidikdan Tenaga Kependidikan Bahasa. Jakarta: PPPPTK Bahasa.

Iskandarwasid, 2013. Strategi Pembelajaran Bahasa. Bandung: PT Remaja Rosdakarya. 
Karma, Lewa.2014. Info. Dinas Pendidikan Propinsi Jawa Timur. Sebagai Sarana Informasi dan Komunikasi.Volume 13, Edisi 12. Surabaya: UPT Tekkomdik Dinas Pendidikan Prov. Jatim.

Kemendiknas. 2010. Pengembangan Budaya dan Karakter Bangsa. Jakarta:Badan Penelitian dan Pengembangan Pusat Kurikulum.

Kosasih, E. 2012. Dasar-dasar Keterampilan Bersastra. Bandung: YramaWidya.

Minderop, Albertine. 2013. Psikologi Sastra. Karya Sastra, Metode, Teori, Dan Contoh Kasus. Jakarta: Yayasan Pustaka Obor Indonesia. Surabaya: Triana Media.

Mustari, Mohammad. 2014. Pelangi. Membangun Manajemen Mutu, Inovasi \& Kreativitas dalam Pendidikan. Jakarta: Direktorat Pembinaan SMP. Pradopo, Rachmat Djoko. 2013. Beberapa Teori Sastra, Metode Kritik, Dan Penerapannya. Yogyakarta: Pustaka Pelajar.

Priandana, Yanu Irdianto. 2014. Hubungan Sastra dan Budaya (Online). Info.com/2013/03/hubungan-sastra-budaya.html, diakses 12 April 2015).

Sarumpaet, RKT. 2010. Pedoman Penelitian Sastra Anak. Edisi Revisi. Jakarta: Yayasan Pustaka Obor Indonesia.

Sugiyono. 2009. Metode Penelitian Pendidikan: Pendekatan Kuantitatif, kualitatif dan $R \& D$. Bandung: Alfabeta.

Sugono, Dendy. 2013. KBBI. Depdikanas. Jakarta: Gramedia.

Supelli, Karlina. Sketsa. 2015. Pendidikan Dari Dan Untuk Pendidikan. Edisi V Maret. Surabaya: Sejahtera Mandiri Teknik.

Widiyarti, Anisa. 2015. Aku Anak Baik. Kumpulan Cerita Menjadi Anak Baik Sesuai Tuntunan Hadits. Solo: Tiga Ananda. 